\title{
Utilising Excess Minibus-taxi Capacity for South African Townships Tours
}

\author{
SEBASTIAAN RIETJENS \\ International Management Group \\ University of Twente \\ PO BOX 217 \\ 7500 AE, Enschede \\ The Netherlands \\ E-mail: s.j.h.rietjens@utwentr.nl
}

\author{
COLLINS MAKORIWA \\ Centre for Transport Studies \\ University of Twente \\ PO BOX 217 \\ 7500 AE, Enschede \\ The Netherlands \\ E-mail: c.makorlwa@ctw.utwente.nl
}

\author{
SIRP DE BOER \\ International Management Group \\ University of Twente \\ PO BOX 217 \\ 7500 AE, Enschede \\ The Netherlands \\ E-mail: s.J.deboer@utwente.nl
}

\section{ABSTRACT}

This paper proposes an option for the utilisation of excess off-peak capacity of minibus-taxis in South Africa for township tours. The minibus-taxi system typically faces steep peak loads during rush hours with excess vehicle and person capacity avallable during off-hours. The advantages of the proposed system include increased direct and indirect income for township residents, higher utllisatlon of scarce capital goods and publicity for industries in the periphery of mainstream tourism. The paper discusses the social and physical environment in South Africa and in particular in the townships. It analyses the changing transport sector of South Africa and then addresses six key issues in the development of an employment-focused township tour system: the market, the minibus-taxi operators, the critical stakeholders, ethics, the organisational structures and the financial feaslbllity. The proposed concept is used for an implementation in Ivory Park, a relatively large township north of Johannesburg.

Keywords: community-based tourism, South Africa, employment creation, township.

Sebastlaan Rletjens completed his MSc in Civil Engineering and Management at the University of Twente, the Netherlands, during which he gained field experlence in Laos and South Africa. As a PhD researcher he is currently involved in a research project on civil-military cooperation in peace support operations. At the University of Twente and the Royal Netherlands Military Academy, Sebastiaan teaches courses on inter alia employmentbased civil engineering and cultural differences.

Collins Makoriwa is currently completing his PhD thesis on measuring transport network performance at the faculty of Civll Engineering at the University of Twente, the Netherlands. Collins has many years of working experlence In several African and Asian countries on developing projects. He supervises several Master students in their research projects.

Sirp de Boer is Associate Professor in International Management at the University of Twente, the Netherlands. His practical experience includes a total of elght years of involvement In development projects in a considerable number of emerging and developing countries. His teaching focuses on country (culture) and sector characteristics, as well as thelr implications for management of organizations. His own research focuses on management of internatlonal technology transfer. 


\section{INTRODUCTION}

Tourism materially benefits a country through its contribution to gross national product, foreign exchange earnings and employment generation (Department of Environmental Affairs and Tourism 2002). It assists in generating wages, salaries and improves business in different communities. In communities in Eastern Europe suffering high unemployment, triggered by the cataclysmic events of the previous decade, tourism has been shown to be an effective catalyst capable of stimulating economic growth and increasing the standard of living (Briedenhann and Wickens 2004). Tourism enriches people's lives, can expand an economy, can be environmentally friendly and can be integrated into a community with minimum impact (Gunn 1994). McKenzie (1994) states: 'the point is not that tourism does not offer potential to poor communities, but rather that people are not currently benefiting from tourism on a scale which fosters their support for the sec-

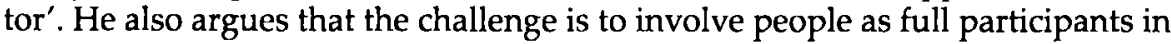
the core of the tourism industry, and not in the margins of the industry. This line of approach is applied in this research.

In the recent past numerous township tours have been developed in South Africa (Soweto and Khayelitsha are well known examples). These township tours show tourists the life in the townships by visiting places of interest such as a local tavern, an informal settlement and a school in this township. These tours, however, are organised by large travel companies that are predominantly white-owned and hence most of the benefits of these trips accrue to a historically privileged social class. The South African government strongly supports a more even distribution of the proceeds from the tourist industry among the population, among other things by stimulating company ownership by historically underprivileged groups in South Africa's society.

This paper focuses on the productive utilisation of the excess capacity of the South African minibus-taxi industry available during off-peak hours within these township tours. One observes that to meet the demand during peak hours, it is often a requirement that an over-investment is made in transportation capacity regarding both persons and vehicles. This over-investment has two implications: 1) the users during peak hours pay for the excess investment, and 2) the employees and operators in the industry do not earn as much as they could due to the under utilisation during off-peak hours. The objective of the research was to develop a project that will result in increased productivity of the workers and vehicles in the minibus-taxi industry, while taking cognisance of the changing legislative landscape and social conditions in the townships. The constraints in the research were that the project would require as little investments of additional funds as possible from the entrepreneurs and create as much employment as possible while remaining economically viable. It was deemed desirable that the control and ownership of the various elements should be as widespread as possible; hence the creation of a large corporate entity is not an attractive option.

To establish the existence and magnitude of non-technical issues that will have an impact on the technical proposals developed a brief background study on the social and physical environment in South Africa is undertaken first. Next, an 
analysis of the public transportation industry in South Africa is made, since it is expected to undergo significant changes, motivated by legislation. Following this, the core section develops the concept of a township tour, in which minibustaxis can actively participate. It addresses six key issues: the market, the minibus-taxi operators, the critical stakeholders, ethics, the organisational structures and the financial feasibility. Subsequently, an implementation strategy for the development of such a project in Ivory Park, a township close to Johannesburg is described. The study concludes by summarising the attractiveness of the project and the possible benefits to the government, taxi-operators as well as the township residents.

\section{LITERATURE REVIEW}

In order to arrive at an appropriate description of the context of this paper's core issue the following sections provide an overview of the relevant social, physical and transportation characteristics. This selection of context issues was made in view of the character of the subject. Firstly, the social environment is addressed as the type of tourism at hand concerns social deprivation and contrasts, resulting from political and economic issues at the different levels of administration. An understanding of the social dimension is therefore required in order to understand the relevance of employment generation and of considering the considerable gap between those visited and their visitors. Next, the physical environment is discussed. This feature is particularly relevant in describing the background of the system of minibus-taxis and their availability. As a logical follow-up, the minibus-taxi system itself is described. As there is considerable demand, the minibus-taxis are prone to irregularities which in turn require regulation and control.

\section{Social Environment}

After decades under white minority rule, South Africa is still adjusting to a normal life. The election of Nelson Mandela as president in 1994 unleashed great hopes for a better life for the majority of South Africa's people, hopes that have proved too great to fulfil so far. Optimism remains high and things are changing. However, many still identify themselves by, and live according to their race. An unemployment rate of $41 \%$ (Kingdon and Knight 2004) and a HIV/AIDS caseload of 5.5 million (Baleta 2004; Madhavan 2004) are compounding the government's difficulties in redistributing wealth among the country's poor. Unemployment in South Africa is today seen as the prime underlying reason for several social maladies such as erosion of human capital, crime, social exclusion and sectored instability. Table 1 shows the unemployment in South Africa compared to other countries. It shows a crucial element, which is the role of the informal sector in absorbing human capital. Too little binds the rich white community to their poorer black neighbours, apart from a shared fear of spiralling crime and a love of sport.

The implications of the data presented in the table above are that the informal sector could be an unexploited employment creation growth engine. Further-

Volume 17 - Number 1 . Summer 2006 . 
Table 1. Urban unemployment and employment rate in informal sector (\%)

\begin{tabular}{lccr}
\hline & $\begin{array}{c}\text { Urban } \\
\text { unemployment }\end{array}$ & $\begin{array}{r}\text { Employment } \\
\text { rate in informal } \\
\text { sector }\end{array}$ & $\begin{array}{r}\text { Ratio of informal } \\
\text { sector employment } \\
\text { to unemployment }\end{array}$ \\
\hline South Africa & 27.0 & 18.9 & 0.7 \\
Mali & 9.9 & 78.6 & 7.9 \\
Kenya & 16.2 & 71.6 & 4.4 \\
Brazil & 4.6 & 57.6 & 12.5 \\
Mexico & 6.3 & 59.4 & 9.4 \\
Sub-Saharan Africa & 16.0 & 74.8 & 4.7 \\
Latin America & 8.1 & 56.9 & 7.0 \\
Asia & 5.3 & 63.0 & 11.9 \\
\hline
\end{tabular}

Source: Kingdon and Knight 2004.

more, studies by Kingdon and Knight (2004) show that the wages in the informal/ self employed sector are much less than those in waged employment and that most people prefer to search for waged jobs while unemployed rather than search for jobs while working in the informal sector. It is therefore imperative that the conditions and solutions adopted create employment in the informal sector resulting in a more structured industry that is perceived as safe and attractive to be working in.

Today, more than two-thirds of blacks still live in poverty while fewer than one in ten whites is poor, and sluggish economic growth is doing very little to alleviate unemployment, currently at $30 \%$, considered one of the highest in the world. In many townships this percentage is estimated to be even higher. It is one of the main targets of the South African government to reduce unemployment and underemployment. Underemployment of both persons and resources means that the few persons who have the opportunity to work do not produce as much as they could produce, and also that the expensive investments made in various factors of production are not fully utilised.

\section{Physical Environment}

The spatial planning of the cities in South Africa is heavily influenced by the legislation passed in the Apartheid era. The 1913 Land Act prohibited Black people outside designated areas. In 1950, the government passed an act that classified citizens as Indian, Coloured, Black or White. This was followed by legislation in 1951 that enforced physical racial segregation in urban areas based on the 1951 classification. The urban areas thus evolved into a system where migrant labour was housed in townships and these townships were in turn shaped by migrant labour. The townships have several common characteristics features. Townships are located at a significant distance from the city centre and often have neither industries nor employment opportunities. They usually house an impoverished population and have significantly higher crime rates than the urban areas. Finally, most townships have a weak local authority/ government system.

The spatial setup of these areas thus demands the availability of public transport for people who have jobs to access the jobs. The townships are thus pre- 
dominantly mono-functional and without transportation, implying there are very few livelihood options. This is manifested in the long average trip lengths on transit facilities as well as a high difference between peak and off peak demand for public transportation. While it is the desire of the government that desegregation takes place, there is no active plan to desegregate or create mixed land use areas, which will minimise transportation dependence in urban areas. Indeed, all desegregation or urban changes in South Africa are today driven by service delivery and market based regulation of land use (Bond 1999).

\section{Transport Analysis}

The minibus-taxi is the most widely used mode of public transportation in South Africa. Minibus-taxi trips constitute approximately $65 \%$ of all the passenger trips made by public transport (SAGI 2005). There are 40000 taxi operators (operator here refers to owner, and taxi refers to a 16-seater commuter bus) who run about 120000 minibus-taxis in South Africa which bear the signature of the apartheid regime. The operators are licensed to run their vehicles on unscheduled routes i.e. they are licensed to run their vehicles on certain routes but they are not obliged to conform to any operating schedule. The average length of an urban commute in these minibus-taxis is about $18 \mathrm{~km}$, which is quite a significant distance, a fact attributed to the urban planning of the larger cities in South Africa. The street layout in most of these city centres is a grid format, similar to streets in cities that begun in the late 18th and 19th century e.g. Nairobi, Washington DC. There is a ring road around the city and main radial arterials that join the ring road. With this spatial layout, one would expect intense demand for transit during peak hours. Moreover, this extreme reliance on transit will not change in the foreseeable future, as it would require significant land use changes in the main cities in South Africa, a task that takes decades before significant effects are seen. Indeed, if any changes are expected in the short run, it would be increased motorization due to a move from transit to private vehicles that would further increase the pressure on the road system.

The average age of the minibus-taxi fleet is rapidly increasing due to insufficient investment in vehicle replacement. Besides, the minibus-taxi industry is plagued by several problems some of which include bad organisation of the industry, crime, the oversupply of vehicles and the drivers, who need improved driving skills (Fourie 2003). Further aggravating the precarious situation of investors in minibus-taxis is the impending introduction of legislation that will see the replacement of small vehicles with larger bus-size vehicles (i.e. new taxi vehicle) under the recapitalisation project. The second main component of this project is the introduction of an electronic management system. The primary objectives of this initiative are to rationalize the utilization of resources in the transport sector with improved services to users, increased efficiency of resource (e.g. energy, vehicles) utilization, increased safety and a move from cash-based to cash-less transport system. It is estimated that the component related to vehicle replacement will cost about 7.7 
billion Rand (i.e. approximately 1.26 billion US\$) (Department of Transport 2004, 2000, 1998).

In the short run, there is a need to regulate and control the transport industry in South Africa. If the recapitalisation programme is to attract the funding of private investors as well as government, there is a need for the minibustaxi industry to show an ability to adhere to a framework that governs its operation. The key issues identified by a study into this by the Department of Transport are: the recapitalisation programme, the issue of subsidies, labour issues, training and capacity building, and related business opportunities. Of this list, item 3 to 5 are of utmost interest to this study, as these concern the taxi operators directly. The unregulated and highly competitive environment coupled with high unemployment rates in South Africa, results in the unique and often undesirable behaviour among the workers of the minibus-taxi industry. The taxi operators demand a certain minimum return per day from the vehicle drivers. It is thus in the drivers' interest to exceed this limit by as much as possible because it then provides an opportunity for "extra income". Drivers and conductors work extremely long days - with the very high unemployment nobody complains. Moreover, taxi operators have formed "gangs" to defend "their routes" against intrusion by new service providers hence the infamous taxi wars that sometimes break out.

\section{Township Tour Framework and Methodology}

To increase the productivity of the workers and the vehicles in the minibustaxi industry by utilising the excess capacity to participate in a township tour has several reasons. First, the time fits the low peak of transport and is therefore complementary. Such a project can therefore become a first step for minibus-taxis, to get involved in the growing tourism industry and it can contribute in the upgrading of the negative image of the minibus-taxi industry. The project can also contribute in expanding the revenues for the minibus-taxi industry, which are needed to cover the extra costs arising from the recapitalisation project. Secondly, the townships will get involved in the tourism industry arid nence it targets the poor. Thirdly, it breeds other auxiliary industries such as the cottage industries to supply tourism with artefacts such as souvenirs. Finally, it is in line with existing legislation that will scrap the use of minibustaxis and hence will make use of the minibus-taxis in time.

To develop a township tour in which the minibus-taxi industry actively participates, several actions have been undertaken. A stakeholder analysis identified all potential stakeholders, their interests, the potential impact of these interests on the township tour and the relative priorities of interest. An evaluation of existing township tourism projects in Johannesburg, East London, Port Elizabeth and Cape Town provided information on the operations of a township tour, the finances, the organisational structures, the socio-cultural aspects and implementation difficulties. To carry out the stakeholder analysis and the evaluations we held 70 interviews with township tour operators, inhabitants of the townships, minibus-taxi owners and drivers, township au- 
thorities (e.g. police, representatives) and transport experts. In addition several other sources were consulted including government policy plans, project documentation and crime figures.

Making use of a Logical Framework Analysis structured the issues which were derived from both the stakeholder analysis and the evaluation of existing township tourism projects. The Logical Framework Analysis was developed as a methodology for development-related projects that enables the user to present a comprehensive overview of the issues and problems at hand and to transform these into a consistent set of objectives and strategies. The following six key issues were identified to be important for the development of a township tour: market, minibus-taxi operators, critical stakeholders, ethics, organisational structures and financial feasibility (Rietjens and Bulsink 2001). These issues are elaborated in the following sections.

\section{Market}

To attract a sufficient number of tourists for a township tour five aspects are essential: price, attractiveness, advertisement, safety and potential number of tourists (Rietjens and Bulsink 2001). The market structure of township tourism is classified as an oligopoly, which is a structure with a limited number of suppliers in the region. Because a newly created township tour organisation still lacks the power to dictate the market, the price strategy should be a pricefollowing strategy (Wit and Gent 2001). The determination of the price should therefore be based on the price of the competitors. The price of most existing township tours is approximately R 180 and the price of a newly created township tour should therefore also be $\mathrm{R} 180$.

The attractiveness is largely determined by the attractions that are visited during the township tour and the quality of the guides. To integrate special attractions in the township tour, like churches and special community projects, can be important, because basically every existing township tour is the same. In order to spread the benefits of the township tour, three different guides can be employed. The main guide provides the guiding on the minibus-taxi and two special guides fulfil smaller guiding activities by showing the tourists around in a squatter camp (i.e. an illegal and informal settlement) and by presenting the tourists a shack (i.e. a small informal settlement). Such visits not only provide a really close look into a township's society, but also facilitate intimate and personal stories of the different local guides engaged in the tour.

A brochure and a web-homepage are adequate means to advertise for a township tour. A brochure can be distributed via local tourism offices, hotels, bed \& breakfast places, airports, conference centres and other gathering places for tourists. A web-homepage of the township tour, with the same information as in the brochure can be made to attract tourists, who are planning a trip from their home country. Other ways to increase the publicity of the tour are short reports in tourist magazines and newspaper-type materials and increased emphasis on the special characteristics of maximum involvement of the local community. Including the township tour in local and international travel guides is attractive as well, though this needs a longer term effort. 
To ensure the safety of a township tour a first knowledge of safe places of the township should be gathered. A safety-map with information related to these safe places is therefore necessary. Secondly, safety in the minibus-taxis has to be created and maintained. Therefore only safe and reliable vehicles have to be selected, the driving and tourism skills of participating drivers have to be improved and the violence and crime between minibus-taxis have to be minimised. Thirdly, a township tour should not be done under police protection. However, the local police should be informed about the project and should be consulted on the safety of the areas. Cooperation with the political representatives of the township and the creation of a community trust fund (see critical stakeholders) can indirectly contribute to the safety of the tourists. This is because due to the community bondage potential criminals are then more aware of the negative consequences for the township as a whole (in terms of negative publicity and thus reduced tourist numbers) if they assault participating tourists in a township tour.

To determine the potential number of visitors to a township tour, we took into account the number of days spent by foreign tourists at five main cities (see Table 2) and the number of tourists that currently take a township tour near these cities (see Table 3). From the tables one can derive that approximately $6 \%$ of all foreign tourists, who visit South Africa, take a township tour. This leaves considerable space for a township tour to attract a sufficient number of tourists. Moreover, Soweto and to a smaller extent KwaMagxaki and the Cape Flats, appear to be the only townships in South Africa in which a township tour was effectively introduced. However, most of these tours are provided by white-owned tourism enterprises. Although these enterprises do sometimes employ local people, they benefit from it only to a limited extent as most profits flow to the white owners.

\section{Minibus-taxi Operators}

A sufficient number of minibus-taxi operators are willing to participate in the project if they can see the benefits that can accrue to them. Based on a criteria list, the capability of each operator with his minibus-taxi can be determined. Suggested criteria are possession of all the appropriate licenses and

Table 2. Number of days spent by foreign tourists in South Africa

\begin{tabular}{|c|c|c|c|}
\hline Location & $\begin{array}{l}\text { Number of foreign } \\
\text { visitors in } 2004\end{array}$ & $\begin{array}{c}\text { Average number } \\
\text { of days spent } \\
\text { at location }\end{array}$ & $\begin{array}{r}\text { Total number } \\
\text { of days spent } \\
\text { by foreign } \\
\text { tourists at location }\end{array}$ \\
\hline Gauteng (Johannesburg) & 3392342 & 5.26 & 17848994 \\
\hline Western Cape (Cape Town) & 1529225 & 10.54 & 16121672 \\
\hline KwaZulu Natal (Durban) & 1362279 & .34 & 8636610 \\
\hline $\begin{array}{l}\text { Eastern cape } \\
\text { (Port Elizabeth \& East London) }\end{array}$ & 520871 & 6.63 & 3454644 \\
\hline Total South Africa & 6677839 & 8.60 & 57577400 \\
\hline
\end{tabular}

Source: SATOUR 2005. 
Table 3. Estimated number of tourists who take a township tour in 2004

\begin{tabular}{|c|c|c|c|c|c|}
\hline Number of tourists: & $\begin{array}{c}\text { Soweto } \\
\text { Johannesburg) }\end{array}$ & $\begin{array}{c}\text { Mdantsane } \\
\text { (East London) }\end{array}$ & $\begin{array}{c}\text { KwaMagxaki } \\
\text { (Port Elizabeth) }\end{array}$ & $\begin{array}{l}\text { Cape Flats } \\
\text { (Cape Town) }\end{array}$ & Total \\
\hline 1. Number of minibuses & 100 & 1 & 10 & 15 & \\
\hline 2. Frequency of tours per day & 2 & $2 / 7$ & 2 & 2 & \\
\hline 3. Average number of tourists on tour & 4 & 4 & 4 & 6 & \\
\hline Total number of tourists per day & 800 & 1 & 80 & 180 & 1061 \\
\hline
\end{tabular}

Source: Interviews with Calabash Tours and Nikki's Tours in Port Elizabeth, Grass roots Tours in Cape Town, Jeffs's Tours and Once More Tours in Johannesburg, African Experience Tours in East London.

permits (i.e. Road Transportation Permit, public driving permit); age of the minibus-taxi; representation of the minibus-taxi from the inside and outside (i.e. broken windows, clean vehicle, easy entrance, broken parts in sight); AA (Automobile Association) registration of the minibus-taxi. Moreover, each participating operator has to do a course on business skills. Minibus-taxi operators can be committed to the project through a financial interest. Therefore each operator has to pay a straight fee and a monthly subscription.

Because of the superior position of a minibus-taxi operator to a driver, a driver normally has to accept a decision of his employer. However, the driver has to be motivated. Showing him or her the benefits of the project can do this. The capability of a driver can be determined through another list of criteria (Rietjens and Bulsink 2001). Suggested criteria are possession of valid driver's license; ability and willingness to take an advanced driving course and a basic tourism training course; understanding of English; ability to work three days a week; possession of a cell phone. Moreover, each participating driver has to do a basic tourism course. Drivers can be committed to the project through a financial interest. Letting the drivers pay back the training costs can do this.

\section{Critical Stakeholders}

Three stakeholders are identified as critical, without whose support a township tour is likely to fail (Rietjens and Bulsink 2001). These stakeholders are (1) the political representation of the township, (2) the inhabitants of the township and (3) the minibus-taxi operators of the township, which are not involved in the township tour. The political representatives do not have any personal or direct benefit from the township tour. However, since they are often very influential in the township their cooperation is needed. Cooperation of the political representation starts by informing all the political representatives. This has to be done in an early stage of the project by having several meetings with all the political representatives. In these meetings the objectives and the functioning of the project should be made clear. It is important to stress that the project is developed for the benefit of the community of the township. No community project succeeds without the support of the inhabitants. In order to get this support, the inhabitants have to be involved in and benefit from the township tour. The following inhabitants are involved and benefit from the project: 
- Minibus-taxi owners, minibus-taxi drivers and the inhabitants who work as a guide; these people get paid directly for their activities within the township tour,

- Shopkeepers; residents of the townships, who sell goods (e.g. wooden artefacts) in their shops, along the road (hawkers), or in a tent (spaza) that might be interesting for the tourists.

Inhabitants, who are not involved can still benefit from the township tour as part of the monthly benefits go directly to a community trust fund. The creation of this fund enables the township to initiate additional community projects. Moreover, township tourism is an opportunity to show the inhabitants that community projects are benefiting the whole community. In order to make sure that minibus-taxi owners, who are not involved, do not block the township tour, several measures can be taken. First, a clear explanation of the project to all the minibus-taxi owners should be given. This includes a clear description of the criteria, which have to be fulfilled in order to participate in the project. A second measure that can be taken is the creation of a community trust fund, to which a part of the benefits flow. From this fund, also the owners, who are not involved, and their relatives benefit.

\section{Ethics}

What the tourists are interested in concerns to a considerable extent the deprived situation of fellow human beings. What about the impact of township tourism on the persons who are the objects of such tourism? Besides being gazed at they face a big gap in personal wealth between their visitors and themselves. The income they will derive from such tourism is rather seasonal in nature, causing job insecurity to them as well as to all others involved (e.g. guides, drivers). Obviously, some persons in a township will benefit more from tourism than others. On the positive impact side of township tourism we mentioned the economic benefits to township inhabitants as well as opportunities for skills development and participation in (self-employed) hosting activities.

Altogether, it is a matter of finding an appropriate balance to optimize the benefits and mitigate the drawbacks. This is fully in line with what the World Tourism Organization proposes in its Global Code of Ethics for Tourism (WTO 1999). This code specifies a framework for all stakeholders to achieve the responsible and sustainable development of world tourism. It emphasizes the professional set-up and execution of programs in order to: observe the social and cultural traditions and practices of the persons involved, sharing equitably, avoiding exploitation, and protecting the natural heritage. A township tour provides a personal familiarization with the prevailing social and cultural practices of township residents. It implies that the participants should respect the situation shown to them, while the guides may need to warn participants that such a visit may be poignant.

In the case of township tours particular attention needs to be paid to the voluntary cooperation and well-being of township residents, as their involvement 
may lead to jealous feelings among other township residents. In the specific context of townships the security of the relatively rich visitors also requires special care, including a way to deal with township residents wanting to beg for alms from the foreign guests. A relatively high degree of control is required to counter the jungle-type situation common in many townships. Direct control mechanisms, such as informing township elders and the police, should ensure that no one's well-being is at risk. Indirect control mechanisms can be applied, such as sharing equitably in the benefits of a township tour by involving township residents not only as tourist staff but also as investors.

\section{Organisational Structures}

To set up the organisational structure of a township tour, basically two choices are to be made. The first is choice is one between an entrepreneur-based approach and a community-based approach. An entrepreneur-based approach is mainly concerned with emerging small, medium and micro enterprises (SMMEs) and free-market principles. A community-based approach is more focused on spreading the benefits of a project through the community. The differences between both approaches are presented in Table 4 .

It is concluded that in this case a community-based approach is more desirable. This is mainly because the characteristics of this approach agree with the objectives of the project (i.e. employment creation in a township and the benefits of the poor communities from tourism). However, there are also some

Table 4. Differences between entrepreneur-based and community-based approaches

\begin{tabular}{ll}
\hline Entrepreneur-based approach & Community-based approach \\
$\begin{array}{l}\text { 1. The benefits are mainly divided among } \\
\text { a few beneficiaries }\end{array}$ & $\begin{array}{l}\text { The benefits are spread out } \\
\text { through the community (McKenzie, 1994) }\end{array}$ \\
\hline $\begin{array}{l}\text { 2. A few SMMEs are the main } \\
\text { stakeholders }\end{array}$ & $\begin{array}{l}\text { A greater part of the community } \\
\text { participates }\end{array}$ \\
\hline $\begin{array}{l}\text { 3. Envy between non-participants } \\
\text { and participants }\end{array}$ & $\begin{array}{l}\text { Less jealousy, because the community } \\
\text { benefits from the project }\end{array}$ \\
\hline $\begin{array}{l}\text { 4. Difficult to get government support } \\
\text { on basis of social benefits }\end{array}$ & $\begin{array}{l}\text { Easier to get government support } \\
\text { on social benefits }\end{array}$ \\
\hline $\begin{array}{l}\text { 5. Less support because of not } \\
\text { spreading benefits }\end{array}$ & \begin{tabular}{l} 
Support because of spreading benefits \\
\hline 6. Not spreading the risks of failure
\end{tabular} \\
\hline $\begin{array}{l}\text { 7. Experience with approach in } \\
\text { urban areas }\end{array}$ & $\begin{array}{l}\text { Spreading the risks of failure } \\
\text { 8. Less people have to be trained }\end{array}$ \\
\hline \begin{tabular}{l} 
9. Easier to implement \\
\hline 10. People work harder for a gain
\end{tabular} \\
\hline
\end{tabular}

Source: Rietjens and Bulsink 2001. 
disadvantages like the lack of experience in urban areas, the difficulty to implement this approach and the lack of motivation to work hard, which have to be dealt with. In addition, a community-based approach has less space for private initiative and is thus less innovative compared to an entrepreneurbased approach.

The second choice is whether or not a business linkage with a tourism enterprise has to be formed. Rogerson (2001) identified several key drivers of business linkages in tourism (e.g. government policy, product differentiation, cost-cutting and efficiency). An analysis of these key drivers shows that business linkages between South African tourism enterprises and the stakeholders within a township tourism project are desirable (Rietjens and Bulsink 2001). The tourism enterprises can differentiate their product and start a township tour without disturbing local stability. The stakeholders of the township (i.e. minibus-taxi owners and drivers, inhabitants, shopkeepers) can benefit from a business linkage through inter alia training and access to finance, administration and advertisement. In return the tourism enterprise receives a monthly allowance. It is also in line with South African government's policy which is to reward a tourism enterprise commercially (e.g. grant of licences, after concessions of finance.

The most preferable organisation structure is thus a community-based approach with a business linkage to a company. A township tour organisation functions as an intermediate between the minibus-taxis and guides on the one side and the external stakeholders (e.g. tourists, city council and company involved in business linkage) on the other side. Its role is to facilitate and manage the township tour. The core function, all operational activities, is carried out by the manager and a secretary. Strategy and guidelines for operation are set by a Board of Trustees representing the main stakeholders (social and political representation, taxi associations, representatives of local departments of transport, tourism and labour), ensuring that there is adequate support for the township tours to take place.

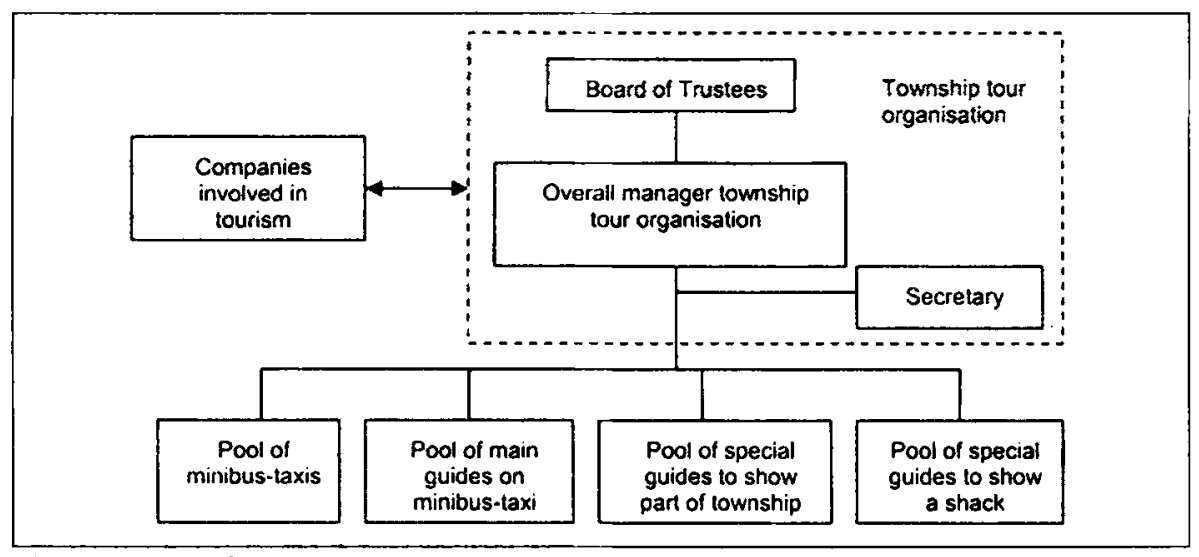

Figure 1. Proposed organisation structure 
This organisation structure also results in increased participation of several small enterprises and hence increased distribution of the income generated by the industry. Therefore all activities are divided between many participants. Also, this preferable organisation structure implies the support (i.e. financial, administrative and commercial) of a company, involved in tourism. The organisation structure can therefore be presented as in Figure 1.

The legal structure consists of transportation guidelines, tourism guidelines and employment guidelines. Each of these guidelines implies several legal actions to be taken. The transportation guidelines imply the requirement of various documents for participating persons and vehicles. A Road Transportation Permit for each participating vehicle to regulate and to ensure that the vehicles are safe for public transportation. A public driving permit will provide a guarantee that the driver is suitably trained to drive tourists in addition to a normal valid driving licence of the driver. The tourism guidelines imply the need of administration at the local council and at South African Tourism Board (SATOUR) and the need of General Public Liability Insurance for each participating vehicle. The employment guidelines prescribe the working hours of the employee. From these guidelines it can be concluded that it is legal for minibus-taxi drivers to make overtime above their regular nine hours of peak time (5.00-9.00 am and 14.00-19.00 pm) during 10 hours a week, with a maximum of three hours a day. Therefore the duration of a township tour should be restricted to three hours and each minibus-taxi driver is not allowed to do more than three tours a week.

Many alternatives are available to fund the development activities for township tour industry and also to sustain the various administrative activities required to run the industry. First, involved minibus-taxi operators pay a straight fee and a monthly subscription to participate in the project. Secondly, project developers can pay a fee, if their project is integrated in the township tour. Thirdly, when a business linkage can be established with a company involved in tourism, this company will financially support the project. Finally, finance can be accessed by loans of commercial banks, the Development Bank of Southern Africa, the local Chamber of Commerce (COC), the local City Council or government authorities. By involving different private (banks), governmental (city council) and non-governmental organizations (chamber of commerce) in their establishment and improvement, township tours become an integral part of the wider society. This is expected to enhance their continuity and growth.

\section{Financial Feasibility}

To assess the financial feasibility of a township tour in South Africa costs and benefits have to be determined. Start up costs include road transportation permits, training for both the drivers and the guides and advertisement amongst others and have been estimated on $\mathrm{R} 65000$. Once the project has started the overhead costs include the rental of a tourism office, insurance, a secretary and advertisement costs. Based on interviews with SATOUR and various tour 
operators these costs have been estimated on $\mathrm{R} 7000$ per month. The variable costs are composed of the salary of the drivers, minibus-taxi operators and guides and have been estimated on $R 360$ per township tour (Rietjens and Bulsink 2001).

Four possible options for funding a minibus-taxi tourism project are proposed. First, each involved minibus-taxi owner should pay a buy in fee of $R 1000$. After this, a monthly fee of R200 has to be paid by each owner. Second, the project developers in the township, who are interested in a township tour, can invest in the project or integrate their own project into a township tour in return for money. The third option depends on the organisation structure that is chosen. In case of a business linkage, the township tour is mainly funded by the large tourism enterprise. This tourism enterprise funds the start-up costs and takes care of the advertisement, the administration and fulfils a mentorship role of the township tour organisation. Once the tour is running, the township tour organisation starts repaying its debts to the tourism enterprise. Finally, the tourists, who take part in the township tour each pay $R 180$, which was the price of most existing township tours.

Figure 2 shows that at least 26 township tours per month have to be made to make the project financially feasible if on average four tourists take part in a township tour (Rietjens and Bulsink, 2001). If a township tour attracts on average only three tourists, the equilibrium to make the project financially feasible increases to 55 township tours per month. Each additional township tour can contribute to the funding of community projects through the community trust fund.

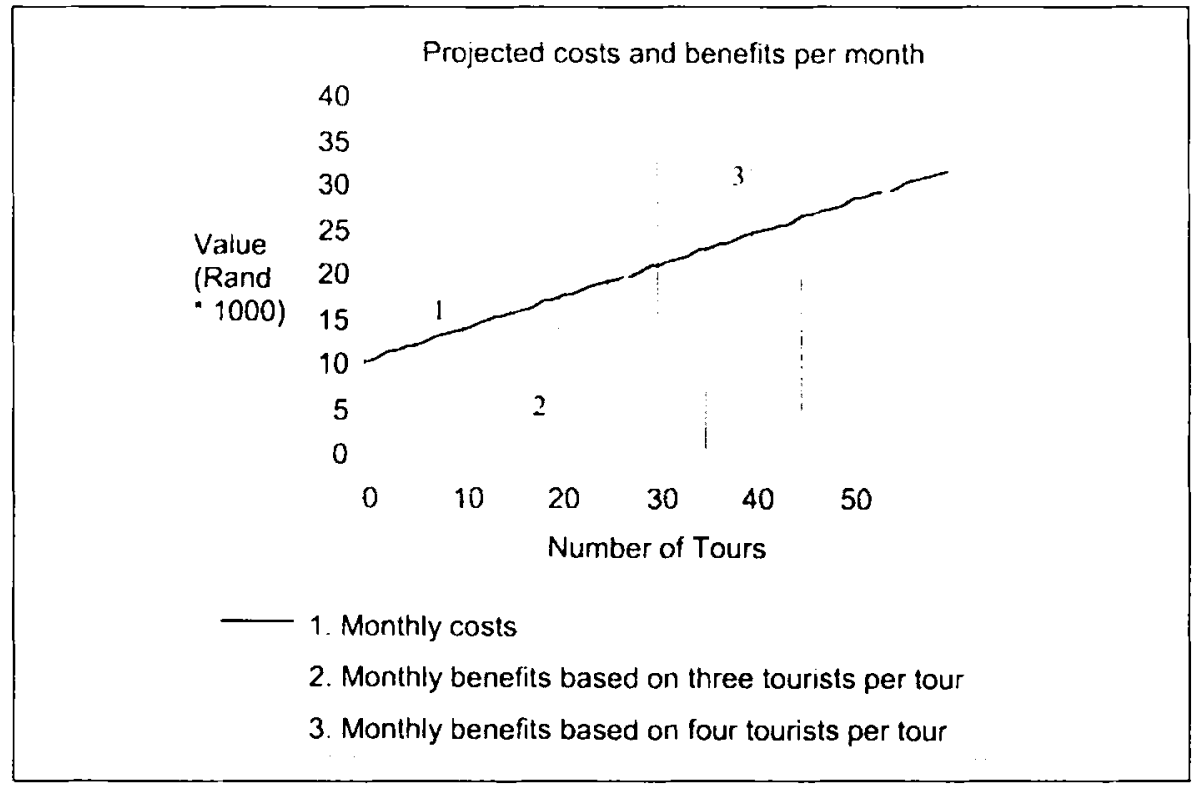

Figure 2. Costs and benefits per month 


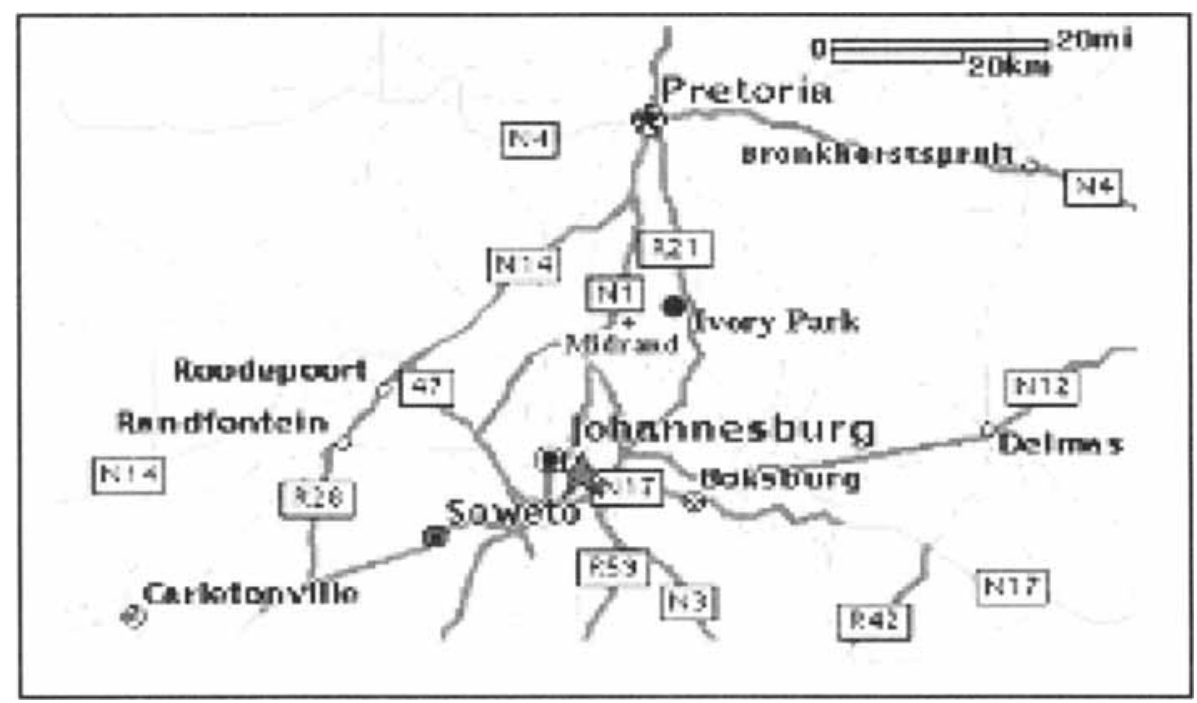

Map 1. Location of Ivory Park

\section{Implementation in Ivory Park}

Ivory Park is situated about 20 kilometres north of Johannesburg and it covers an area of approximately 1200 hectares within the municipality of Midrand. It is one of the biggest townships in South Africa, with an estimated number of 200000 inhabitants (Leahy 2004). The majority of the people are still living in shacks, but every day 30 brick houses are built. Such developments do not only underline the national and local governments' ambition to meet real needs of people, they also bear witness of a modern approach of urban planning, though still along traditional lines of separating living and working.

There are several reasons to select Ivory Park as implementation area. First, Ivory Park is strategically situated between Johannesburg and Pretoria. Second, the township has got many special attractions like Eco-City projects (e.g. eco-village, a wetlands system and an organic market) and Afribike (i.e. an organisation, which focuses on the introduction of bicycles in developing areas like Ivory Park). It is a progressive township and has strong public participation. This can clearly facilitate the implementation process. Finally, like most townships, there are hardly any employment opportunities in Ivory Park except for small retail grocery shops, which are only capable of providing employment for the proprietor. Despite the attractiveness of the nearby Soweto, a township tour in Ivory Park has got great potential. On a yearly basis Johannesburg attracts nearly 3.4 million tourists who spend on average 5.26 days in Gauteng province (SATOUR 2005). Compared to Soweto, Ivory Park is situated much closer to the conference centres, the international airport of Johannesburg and the city of Pretoria. 
Implementation of a township tour in Ivory Park, in which the minibus-taxi industry actively participates, results in several main tasks. First, a short-term overall manager with high-level capacities is appointed to initiate the project in approximately seven months. After initiation an overall-manager with midlevel capacities can take over the activities. In the initiation phase, crucial tasks are the consultation of the stakeholders, the selection of the minibus-taxis and guides, training, financial arrangements and some smaller operational activities (e.g. development of route, advertisement). The project also formulates a training scheme and certification process for participants in the project. It is envisaged that this will guarantee a certain code of conduct is followed and maintained by the workers in the taxi-tourism business. Though this is a small portion of the entire taxi industry, it could serve as a pilot project or phase for the training and certification of the larger industry when the new taxi vehicles are introduced. The initiation phase takes approximately 24 weeks.

In the operational phase, the recruitment of new guides and drivers and the development of small enterprises (e.g. small companies focussed on the tourism industry) should be stressed. In both the initiation phase and the operational phase, communication with the inhabitants of Ivory Park can be best done through the councillors of the three wards.

\section{CONCLUSIONS AND IMPLICATIONS}

The objective of this paper was to develop a project that will result in increased productivity of the workers and vehicles in the minibus-taxi industry, while taking cognisance of the changing legislative landscape. The utilisation of the excess capacity of the minibus-taxis in the tourism industry increases the productivity of both workers and vehicles in the minibus-taxi industry. It therefore provides minibus-taxi operators and drivers with other means of income. Other positive effects of the project are the employment of inhabitants of the township as a guide, the breeding of auxiliary industries, the upgrading of the negative image of the minibus-taxis, the publicity concerning the needs of the people and the integration of the minibus-taxis in the recapitalisation project. Moreover, the project is in line with the existing legislation. Considering the enormous poverty in most townships, the number of direct and indirect jobs, which are created by this project, may be relatively low. However, considering the small investments required this project provides a feasible opportunity to improve the situation in South African townships.

There are also drawbacks of the project. First, the ethical drawbacks such as being gazed at. Second, the job insecurity caused by the seasonal nature of tourism. Finally, the inexperience of implementing such a project. This proposal suggests a robust alternative use for excess capacity while simultaneously addressing key issues facing South Africa, namely alleviation of debilitating unemployment, inequity and insecurity. Moreover, the proposal avoids some of the main problems that tourism faces as an industry, namely, inequity of benefits distribution, perceived social costs to the communities who often do not benefit from the tourism (Jud and Krause 1976) and the involvement of local 
residents in decision making (Briedenhann and Wickers 2004; Britton 1991).

An integral approach of the minibus township tours, such as by the application of the Logical Framework Analysis, provides an appropriate method for the design of a project that addresses the many different aspects of the subject at hand; theory on the way(s) of implementation of such a project, however, is scarce. For practitioners the project design can provide an attractive alternative, which contributes in an optimum way to the increase of local benefits and the excess transport capacity. Future research may include the integration of the minibus-taxi industry in other tourism activities. Trips to National Parks (e.g. Kruger National Park and the Drakensbergen), Swaziland, Lesotho and other tourism attractions have to be considered. Additionally, new sponsorship opportunities have to be examined. The National Department of Transport, project developers and governmental employment creation programmes can be considered as opportunities for sponsorship.

\section{REFERENCES}

Baleta, A. (2004). S African President criticised for lack of focus on AIDS, The Lancet, 363(9408): 541.

Bond, P. (1999). Basic Infrastructure for Socio-economic Development, Environmental Protection and Geographical Desegregation: South Africa's Unmet Challenge, Geoforum, 30(1): 53-59.

Briedenhann J. and Wickens E. (2004). Tourism Routes as a Tool for Economic Development of Rural Areas - Vibrant Hope or Impossible Dream? Tourism Management, 25(1): 71-79.

Britton, S. (1991). Tourism, Capital and Place: Towards a Critical Geography of Tourism, Environment and Planning D: Society \& Space, 9: 451-478.

Department of Environmental Affairs and Tourism (2002). Responsible Tourism Manual for South Africa. Pretoria: Department of Environmental Affairs and Tourism.

Department of Transport (1998). Moving South Africa: A Transport Strategy for 2020. Pretoria: Department of Transport.

Department of Transport (2000). Taxi Recapitalisation Strategy "a Strategic Perspective", 5thDraft. Pretoria: Department of Transport.

Department of Transport (2004). Government Statement on the Taxi Recapitalisation Project. Pretoria: Department of Transport.

Fourie, L.J. (2003). Rethinking the Formalisation of the Minibus-taxi Industry in South Africa. Pretoria: University of Pretoria.

Gunn, C. (1994). Tourism Planning, Basics, Concepts, Cases. Washington DC: Taylor \& Francis.

Jud G. and Krause, W. (1976). Evaluating Tourism in Developing Areas: An Exploratory Enquiry, Journal of Travel Research, 15(2): 1-9.

Kingdon G. and Knight, J. (2004). Unemployment in South Africa: The Nature of the Beast, World Development, 32(3): 391-408.

Leahy, S. (2004). An 'Eco-Town' Takes Root in South Africa. Retrieved October 10, 2005 from the World Wide Web: http://wuru.sustainabletimes.calarticles/EcoCity.htm

Madhavan, S. (2004). Fosterage Patterns in the Age of AIDS: Continuity and Change, Journal of Social Science and Medicine, 50(7): 1443-1454.

Mc Kenzie, P. (1994). A Sociological Study of Tourism in South Africa: A Case Study of Gold Reef City. Johannesburg: University of Witwatersrand.

Rietjens S.J.H. and M.C. Bulsink (2001). Development of a Minibus-taxi Tourism Project in South African Townships. Enschede: University of Twente. 
Rogerson, C.M. (2001). Tourism, Subcontracting and Small Enterprise Development in South Africa. Johannesburg: University of Witwatersrand.

South African Government Information (SAGI) (2005). Transport. Retrieved January 25, 2006 from the World Wide Web: http://www.info.gov.zalaboutsaltransport.htm

South African Tourism Board (SATOUR) (2005). 2004 Annual Tourism Report. Pretoria: SATOUR. Wit de, J. and Gent de, H. (2001). Economie en Transport. Utrecht: Lemma. In Dutch.

World Tourism Organization (WTO) (1999). Global Code of Ethics for Tourism. Retrieved April 19, 2005 from the World Wide Web: http://www.world-tourism.org/projects/ethics/ principles.html

\author{
Submitted :03 November 2005 \\ Resubmitted : 21 February 2006 \\ Resubmitted : 02 March 2006 \\ Accepted : 07 March 2006 \\ Refereed anonymously
}

